Research Article

\title{
A study on the effect of habitual consumption of Madhuca longifolia drinks on the prevalence of diabetes and dyslipidemia among santhal tribals
}

\author{
Arunima Datta ${ }^{1}$, Ayan Pal ${ }^{2}$, Arup Bandyopadhyay ${ }^{\text {* }}$
}

\begin{abstract}
${ }^{1}$ Department of Physiology, ${ }^{2}$ Department of Pharmacology, M.G.M. Medical College and L.S.K. Hospital, Kishanganj, Bihar, India
\end{abstract} Received: 14 April 2016
Accepted: 07 May 2016

*Correspondence to: Dr. Arup Bandyopadhyay, Email: arupbanerjee1953@ gmail.com

Copyright: (C) the author(s), publisher and licensee Medip Academy. This is an openaccess article distributed under the terms of the Creative Commons Attribution NonCommercial License, which permits unrestricted noncommercial use, distribution, and reproduction in any medium, provided the original work is properly cited.

\begin{abstract}
Background: Madhuca longifolia (mahua) is a tropically growing tree found in various parts of India mostly on plain lands. The tree is considered a boon by the tribals who are forest dwellers because of its manifold medicinal properties. Studies show that in animals, alcoholic extracts of this tree produce beneficial effects on diabetic and lipid profile. It is the purpose of this study to know whether these beneficial effects are observed in Santhals many of whom are regular consumers of Madhuca longifolia drinks.

Methods: Diabetic and lipid profile of blood along with standard anthropometric parameters were measured in a population of Santhal tribe (only males were chosen) many of whom, but not all, are regular consumers of mahua drinks. These findings were statistically analysed and compared using student's t-test and inference drawn.

Results: Results show that anthropometric parameters do not differ much, but FBS. $\mathrm{HbA}_{1 \mathrm{c}}$, cholesterol and LDL these parameters are lower in mahua consumers compared to those in non-consumers. HDL is raised in mahua consumers compared to the other group. No significant effect was observed in case of VLDL and triglycerides.

Conclusions: Study shows that regular mahua drinks among Santhal tribe do improve diabetic and lipid profile, except triglycerides and VLDL. Further and more elaborate studies are needed to have proper insight and practical gains in this regard.
\end{abstract}

Keywords: Madhuca longifolia, Mahua, Diabetes mellitus, Lipid profile, Santhal tribe

\section{INTRODUCTION}

Mahua or Mahwa or Iluppai is the common Indian name for Madhuca longifolia which is a common Indian tropical tree found in the central and North Indian plains and forests and also in some parts of Eastern India like West Bengal, Bihar and Jharkhand. It is a fast growing tree that grows to approximately 20 meters in height, possesses evergreen or semi-evergreen foliage, and belongs to the family sapotaceae. ${ }^{1}$

It is cultivated in warm and humid regions for its oleaginous seeds (producing between 20 and $200 \mathrm{~kg}$ of seeds annually per tree, depending on maturity), flowers and also wood.
The botanical classification of Mahua is as follows:

$\begin{array}{ll}\text { Binomial name } & \text { Madhuca longifolia } \\ \text { Kingdom } & \text { Plantae } \\ \text { Order } & \text { Ericates } \\ \text { Family } & \text { Sapotaceae } \\ \text { Genus } & \text { Madhuca } \\ \text { Species } & \text { M. longifolia }\end{array}$

The fat (solid at ambient temperature) is used for the care of the skin, to manufacture soap or detergents and as a vegetable butter. It can also be used as a fuel oil. The seed cakes obtained after extraction of oil constitute very good fertilizer. The flowers are used to produce an alcoholic drink in tropical India. This drink is also known to affect the animals. Several parts of the tree, including 
the bark, are used for their medicinal properties. It is considered holy by many tribal communities because of its manifold usefulness. The tree is considered a boon by the tribals who are forest dwellers and keenly observe the tree. However, conservation of this tree has been marginalized, as it is not favoured by non-tribals.

The Mahua flower is a food item for tribals, a sweetening agent, but most interesting of all is that it can be fermented to produce an alcoholic drink also known as 'mahua'. Tribals of Bastar in Chhattisgarh and Orissa, Santhals of Santhal parganas (Jharkhand) and also Birbhum, Bankura, Midnapur and Purulia districts of West Bengal, Koya tribals of north-east Andhra Pradesh and tribals of north Maharashtra, India consider the mahua drink as a part of their cultural heritage. The main ingredients used for making this drink are 'jhola gur' (granular molasses) and dried mahua flowers. Mahua is an essential drink for tribal men and women during celebrations. The liquor is whitish in colour and having the taste and smell of mahua flower. It is not strong liquor, inexpensive and the production is largely done in home stills.

Methanolic and ethanolic extracts of mahua exhibited a dose-dependent hypoglycemic activity in normal as well as streptozotocin-induced diabetic rats. ${ }^{2,3} \mathrm{We}$ wanted to study the effects of mahua drinks on diabetic and lipid profile in the tribals.

\section{METHODS}

The study was done in a setup of Birbhum district mainly covering three blocks, viz. Labpur, Sainthia and Md. Bazar, where many members of Santhal tribe inhabit for many years and Madhuca longifolia (mahua) trees are abundant. Mahua drink is prepared indigenously by the tribals from Mahua flowers with the help of a unique distillation apparatus consisting of three earthen vessels, the lower one having flower in water, the upper one cold water and the middle vessel with an outlet pipe.

Diabetic and lipid profile of blood along with standard anthropometric parameters were measured in a population of Santhal tribe (only males were chosen) many of whom, but not all, are regular consumers of mahua drinks. These findings were statistically analyzed and compared using student's t-test and inference drawn.

\section{RESULTS}

Table 1: Tabulated results of anthropometric and biochemical parameters of the participants.

\begin{tabular}{|llllll|}
\hline Age & $\begin{array}{l}\text { Mahua group } \\
(\text { mean } \pm \text { SD })\end{array}$ & $\begin{array}{l}\text { Non-mahua group } \\
(\text { mean } \pm \text { SD })\end{array}$ & T-value & P-value & Level of significance \\
\hline Height & $40.33 \pm 12.6$ & $39.27 \pm 13.07$ & 0.32 & 0.75 & Non-significant \\
\hline Weight & $167.83 \pm 7.82$ & $167.46 \pm 8.48$ & 0.17 & 0.86 & Non-significant \\
\hline SBP & $71.76 \pm 10.36$ & $68.03 \pm 10.03$ & 1.41 & 0.16 & Non-significant \\
\hline DBP & $130.27 \pm 24.68$ & $135.2 \pm 31.24$ & 0.68 & 0.5 & Non-significant \\
\hline FBS & $81.13 \pm 9.68$ & $81.47 \pm 9.85$ & 0.13 & 0.9 & Non-significant \\
\hline HbA ${ }_{1 c}$ & $89.97 \pm 26.96$ & $118.9 \pm 46.03$ & 2.97 & 0.004 & Significant \\
\hline Cholesterol & $18.09 \pm 0.53$ & $6.8 \pm 1.15$ & 3.1 & 0.003 & Significant \\
\hline HDL & $48.67 \pm 4.84$ & $207.1 \pm 22.08$ & 3.79 & 0.004 & Significant \\
\hline LDL & $102.03 \pm 28.58$ & $41.47 \pm 7.94$ & 4.24 & 0.0001 & Significant \\
\hline VLDL & $27.63 \pm 5.76$ & $134.67 \pm 17.93$ & 5.3 & 0.0000027 & Significant \\
\hline TG & $138.17 \pm 28.81$ & $138.17 \pm 25.13$ & 0 & 1 & Non-significant \\
\hline
\end{tabular}

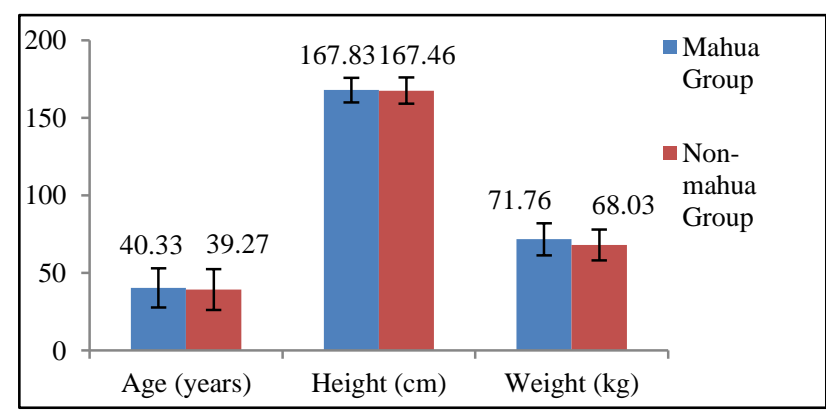

Figure 1: Comparison of demographic profile.

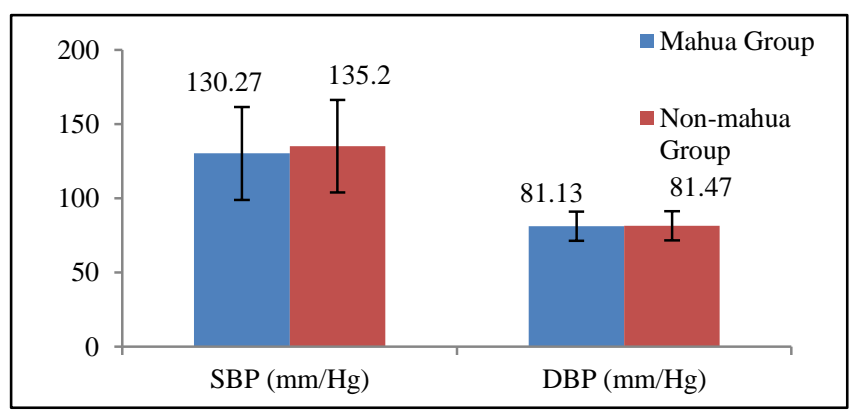

Figure 2: Comparison of SBP and DBP $(\mathrm{mm} / \mathrm{Hg})$. 


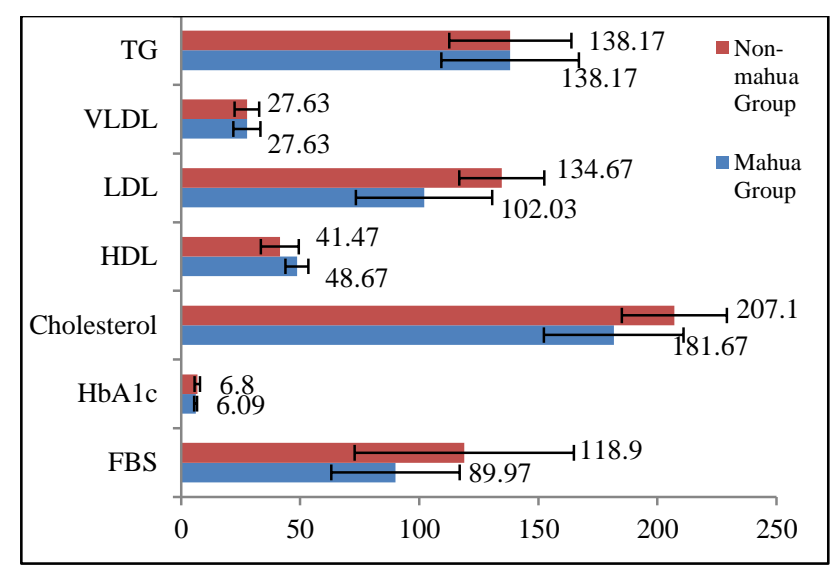

Figure 3: Comparison of biochemical parameters.

\section{DISCUSSION}

In this study, age and sex-wise two equal groups were chosen, of which one group was habitual consumer of mahua drink and the other not. The results show that there was no statistical difference between the two groups regarding height, weight and blood pressure (both systolic and diastolic). However in the regular mahua consumer the mean fasting blood sugar (FBS) was significantly lower than that in non-consumers of mahua $(89.97 \pm 26.96$ vs. $118.9 \pm 56.03 \mathrm{mg} / \mathrm{dl}$ ). Taking $126 \mathrm{mg} / \mathrm{dl}$ level of FBS as cut off level for DM, 10 persons of non-consumers of mahua are fully diabetic compared to only one in mahua consumer group. This strongly suggests that regular consumption of mahua drinks somehow or other prevents the onset of DM. While looking at the lipid profile $(\mathrm{Mean} \pm \mathrm{SD}$ ), we found that the values of total cholesterol, HDL cholesterol, LDL cholesterol, VLDL cholesterol and triglycerides in mahua consumed group are $181.67 \pm 29.38$, $48.67 \pm 4.84,102.03 \pm 28.58,27.63 \pm 5.76$ and $138.17 \pm 28.81$ respectively while those values in the mahua nonconsumer group are 207.1 $\pm 22.08, \quad 41.47 \pm 7.94$, $134.67 \pm 17.93,27.63 \pm 5.13$ and $138.17 \pm 25.65$. All these differences, except those of VLDL and triglycerides are statistically significant. The value of $\mathrm{HbA}_{1 c}$ in mahua consumer group is $6.09 \pm 0.53$ and that in mahua nonconsumer group is $6.8 \pm 1.15$ which is also statistically significant. These findings suggest that regular consumption of mahua improves cholesterol and its lipoprotein components. The rise in HDL-cholesterol is particularly significant as we know that except strenuous exercise and moderate alcohol consumption, it is very difficult to raise HDL-cholesterol, though lowering LDL level is comparatively easy. Interestingly both VLDL cholesterol and triglyceride levels do not change very much in mahua consumers compared to mahua nonconsumers. In this study the values obtained for VLDL cholesterol and triglycerides in mahua consumers $($ mean $\pm S D)$ are $27.63 \pm 5.76 \mathrm{mg} / \mathrm{dl}$ and $138.17 \pm 28.81$ $\mathrm{mg} / \mathrm{dl}$ respectively. On the other hand, these values in mahua non- consumers are $27.63 \pm 5.13$ and $138.17 \pm 25.65$ $\mathrm{mg} / \mathrm{dl}$ respectively. None of these differences are statistically significant.
So far, no study on human beings could be found on antidiabetic effect of Madhuca longifolia. However, there have been quite a few animal studies in-vivo which prove that M. longifolia does have hypoglycemic effects. In a multicentric study done by Pavankumar $\mathrm{K}$ et al male wistar rats were used for this study. ${ }^{4}$ The bark of the plant Madhuca was collected, washed thoroughly with water and dried under shade. Dried pieces of bark were powdered and active substances were extracted with three different solvents such as methanol, petroleum ether and water by soxhlation process. The extracts were evaporated to dryness at a controlled temperature of $45^{\circ} \mathrm{C}$. it was found that lethal dose (actually LD50) for methanolic, petroleum ether and aqueous extract of Madhuca were observed to at $1000 \mathrm{mg} / \mathrm{kg}$ body weight (BW), 1500 $\mathrm{mg} / \mathrm{kg} \mathrm{BW}$ and $2000 \mathrm{mg} / \mathrm{kg} \mathrm{BW}$ respectively. This fatality was possibly due to severe hypoglycaemia. In the study wistar rats were made diabetic either by intraperitoneal injection of proper dose of streptozotocin or both nicotinamide and streptozotocin. Once the rats are made diabetic and confirmed by blood test showing fasting blood glucose (after 16 hours fasting) $>200 \mathrm{mg} / \mathrm{dl}$, they were treated with three extracts of Madhuca in three batches. The animals were thus treated for 30 days with Madhuca, and on the next day, blood was withdrawn by puncturing retro-orbital plexus, serum was separated and serum glucose and lipid profile were estimated. The results showed that streptozotocin raised serum glucose, cholesterol, LDL and triglycerides and decreases HDL, and methanolic extracts of Madhuca significantly reverses all these parameters, but similar significant effects were not found in aqueous and petroleum ether extracts of the herb.

In another study from Gujarat, India performed by Dahake PA et al, the hypoglycemic effect was again studied on streptozotocin induced diabetic wistar rats, of both sexes, with methanolic extracts of Madhuca longifolia and glibenclamide. ${ }^{2}$ The study was done for three weeks after which not only glucose but also serum protein, creatinine and cholesterol were measured. It was found that streptozotocin decreases serum protein but increases glucose, creatinine and cholesterol. The methanolic extract of the bark of the herb reverses these parameters suggesting that the latter not only improves diabetes but also combats the hepatic, renal and lipid complications of streptozotocin induced diabetes.

In still another study, Prasanth $\mathrm{S}$ et al studied on albino rats using ethanolic extract of the bark of Madhuca longifolia. ${ }^{5}$ Oral administration of a single dose of this drug reduced blood glucose in diabetic rats in a dose dependent manner. It was also found by DPPH scavenging method that ethanolic extract of Madhuca Longifolia has a powerful antioxidant activity.

In a further study, done by Ghosh $\mathrm{R}$ et al, hypoglycemic activity of M. longifolia leaves (hyrdo-ethanolic extract) was studied with alloxan induced diabetes in male albino wistar rats. ${ }^{6}$ Whereas both glibenclamide and 
M. longifolia decreases glucose, cholesterol, LDL and triglycerides, the enhancing effect on HDL was only seen in $M$. longifolia treated rats and not with glibenclamide. Activity of G-6-PD, the first regulatory enzyme in pentose phosphate pathway was found to be decreased in diabetic animals and increased in $M$. longifolia treated diabetic rats.

Ours is probably the first scientific study only on human beings showing the effects of oral consumption of $M$. longifolia as a habitual refreshing drink on various parameters of diabetes mellitus viz. FBS and $\mathrm{HbA}_{1 \mathrm{C}}$ and on lipid profile. This study also shows the beneficial effects of $M$. longifolia on diabetes mellitus and lipid profile.

It is therefore, aptly told that M. longifolia is a paradise tree for the tribals.

\section{Conclusion}

Our study suggests that like in animals, in human beings also, regular consumption of Madhuca longifolia extract in the form of a refreshing drink prevents diabetes and improves lipid profile. It shows the pathway that all the components of $M$. longifolia should be distinctly separated and each individual item should be independently and carefully studied to know which fraction(s) of the herb does really contribute to the healing and prevention of diabetes mellitus, the degree of such activity, the prevention of complications and also to rule out possible untoward actions though apparently these are not seen. It is also important to understand the exact mechanism(s) by which this wonderful herb contributes to the healing properties of these ailments.

\section{ACKNOWLEDGEMENT}

The authors would like to thank the Director, Academic Director and Principal, M.G.M. Medical College and L.S.K. hospital, Kishanganj, Bihar and to Pradhans, tribal villagers of Labpur, Sainthia and Md. Bazar blocks of Birbhum District, West Bengal.

Funding: No funding sources

Conflict of interest: None declared

Ethical approval: Not required

\section{REFERENCES}

1. Akshatha KN, Mahadeva MS, Lakshmidevi N. Ethnomedical uses of Madhuca Longifolia-a review. Int J Life Sc Pharma Res. 2013;3(1):44-53.

2. Dahake AP, Chakma CS, Chakma RC, Bagherwal P. Antihyperglycemic activity of methanolic extract of Madhuca Longifolia Bark. 2010;39(1):3-8.

3. Samaresh PR, Shirode D, Tushar P, Shastry CS, Gheewala N, Goutam S, et al. Antioxidant and hepatoprotective activity of Madhuca Longifolia (Koenig) Bark against CCL4 - induced hepatic injury in rats: in-vitro and in-vivo studies. Res J Pharmaceut Biol Chem Sci. 2010;1:1-10.

4. Kumar PK, Vidyasagar G, Ramakrishna D, Reddy MI, Atyam VSSSG and Raidu SCH. Screening of Madhuca Indica for antidiabetic activity in streptozotocin and streptozotocin - nicotinamide induced diabetic rats. Int $\mathbf{J}$ Pharm Tech Res. 2011;3:1073-7.

5. Prashanth S, Kumar AA, Madhu B and Yennamaneni PK. Antihyperglycemic and antioxidant activity of ethanolic extract of madhuca longifolia bark. Int J Pharma Sci Rev Res. 2010;5:89-94.

6. Ghosh R, Dhande I, Kakade VM, Vohra RR, Mehra KV. Antihyperglycemic activity of Madhuca Longifolia in alloxan-induced diabetic rats. Internet $\mathbf{J}$ Pharmacol. 2008;6(2):1-12.

7. Sikarwar RLS. Mahua (Madhuca Longifolia (Koen.) macbride)-a paradise tree for the tribals of Madhya Pradesh. 2002;1(1):87-92.

Cite this article as: Datta A, Pal A,

Bandyopadhyay A. A study on the effect of habitual consumption of Madhuca longifolia drinks on the prevalence of diabetes and dyslipidemia among santhal tribals. Int J Basic Clin Pharmacol 2016;5:1108-11. 